\section{Outcomes of three different models for sex education and citizenship programs concerning knowledge, attitudes, and behavior of Brazilian adolescents}

\author{
Resultados de três programas de educação \\ sexual e cidadania sobre conhecimento, atitude \\ e comportamento de adolescentes brasileiros
}

\author{
Margarita Díaz ${ }^{1}$ \\ Maeve Brito de Mello 2 \\ Maria Helena de Sousa 2 \\ Francisco Cabral 1 \\ Ricardo de Castro e Silva 1 \\ Márcia Campos 3 \\ Anibal Faúndes 2
}

\footnotetext{
1 Reprolatina:

Soluções Inovadoras em Saúde Reprodutiva, Campinas, Brasil.

2 Centro de Pesquisas Materno-Infantis de

Campinas, Campinas, Brasil.

3 Fundação Odebrecht,

Salvador, Brasil.

Correspondence M. Díaz

Reprolatina: Soluções Inovadoras em Saúde Reprodutiva.

Rua Maria Teresa Dias da Silva 740, Campinas, $S P$ 13084-190, Brasil. mdiaz@reprolatina.org.br
}

\begin{abstract}
Three different school-based sex education and citizenship programs in public schools in Rio de Janeiro, Belo Horizonte, and Salvador, Brazil, were evaluated in a cross-sectional study comparing knowledge, attitudes, and practices in sexuality, citizenship, and gender issues among adolescents participating in the programs' activities as compared to adolescents enrolled in schools without such programs (controls). Results showed that Salvador's program achieved good results, with significant changes in knowledge on sexuality and reproductive physiology, attitudes regarding citizenship, and current use of modern contraceptives; Rio de Janeiro's program succeeded in improving students' knowledge of reproductive physiology and attitudes towards sexuality; Belo Horizonte's participants showed greater knowledge of reproductive physiology and STI/HIV prevention but had less positive attitudes towards gender issues, while reporting greater sexual activity. The main difference between Salvador's program and the others was the focus on creative and cultural activities; Belo Horizonte's main difference was its lack of interaction with health services and professionals. However, after the evaluation Belo Horizonte reframed its educational strategies and launched a scaling-up process in a joint effort with the health and school systems.
\end{abstract}

Sex Education; Adolescent; Evaluation

\section{Introduction}

An important decrease in the fertility rate has occurred in the world over the past three decades. In parallel, a proportional increase has been observed in the 10-to-24-year age bracket, to the extent that this group now constitutes nearly one-third of the world's population. In the case of Brazil, this increase in the proportion of adolescents and young adults is the consequence of the relatively high fertility rates of the 1960s, complemented by a sharp decrease in fertility over the past two decades. The size of this age group and its vulnerability in sexual and reproductive health are good reasons for considering it a high priority.

According to a 1999 study by the Centro Brasileiro de Análise e Planejamento 1, 47.0\% of male adolescents (15-19 years) reported sexual initiation before age 15 , as compared to only $35.0 \%$ in 1994 . Although prevalence of contraceptive use among the group of sexually active 15-19-year-olds has increased, reaching $58.8 \%$ and $67.4 \%$ among females and males respectively, according to the 1996 Brazilian Demographic and Health Survey ${ }^{2}$, the consistency and effectiveness of use appear to be poor, since this is the only age group still showing no sign of a decline in fertility. Moreover, according to data from the National STD and AIDS Program, the 25-39-year age group has been the most heavily affected by the AIDS epidemic 
in the country, representing $59.6 \%$ of total cases recorded between 1980 and 20003 . Considering the natural history of AIDS, it is estimated that the maximum frequency of these infections occurred in young people (15 to 24 years).

These problems were the base from which the Brazilian Government launched its National Health Program for Adolescents (PROSAD) in 1988 , with the purpose of promoting the physical, sexual, and psychological health of adolescents as well as supporting their social inclusion. A decade later, in 1998, the Ministry of Education approved the National School Curriculum Guidelines, which established that information on sexual and reproductive health should be a crosscutting theme in all primary and secondary school curricula.

Parallel to this process, beginning in the latter 1980s several nongovernmental organizations (NGOs) and some public institutions launched initiatives focusing on sex education for adolescents. The results of only a few of these initiatives have been systematically evaluated, but most reports have assumed that they were good, effective, or useful because they were well-received by the target population.

Since 1988 the Odebrecht Foundation has supported one of the first and most important private initiatives in adolescent sex education in Brazil. From 1994 to 1997, the Foundation supported three sex education programs in three Brazilian cities, implemented by local NGOs in partnership with the public school and health systems.

The purpose of the current study was to evaluate the outcome of these programs three years after their inception with regard to knowledge, attitudes, and sexual practices of participating adolescents. In addition, some citizenship and gender issues were also studied.

\section{Methods}

\section{The interventions}

The programs evaluated were: the EDUCARTE Program in the city of Rio de Janeiro, Education: an Exercise in Citizenship in Salvador, Bahia, and Sexuality and Affectivity Education in Belo Horizonte, Minas Gerais. Although the three programs were developed independently, they had several commonalities, including the same objective of supporting the social and individual development of adolescents enrolled in public schools.

The three programs shared similar guiding principles, concepts, and methods for working with sexuality, gender, and citizenship as crosscutting themes. All three focused on an expanded concept of sexuality, changing the common comprehension of sexuality as intercourse and adding affectivity to this new dimension. They also focused on the social construction of gender roles, attempting to deconstruct traditional societal roles attributed to men and women. The concept of citizenship was anchored in the principles of human rights. Moreover, adolescents were actively stimulated to take part in the teaching-learning process, and a positive adult-adolescent relationship was promoted in both their schools and families. Finally, schools were encouraged to interact with their own local communities.

Table 1 summarizes the three programs' main characteristics: duration; number of training hours; number of schools and health centers participating; number of schoolteachers, health professionals, and adolescent peer educators trained; and number of adolescents directly involved in each program.

\section{Evaluation}

The programs were evaluated through a joint effort by the Odebrecht Foundation (a nonprofit foundation created and maintained by the Odebrecht Construction and Engineering Company, with headquarters in Salvador, Bahia) and the Maternal and Child Research Center of Campinas (Cemicamp), using a cross-sectional KAP (knowledge, attitudes, and practice) study. The knowledge, attitudes, and practices of adolescents who participated in the sex education programs were compared with those of adolescents enrolled in schools that did not have such programs in their curricula, separately for each municipality. Although the evaluation was performed by a research team not involved in the interventions, almost all phases of the process were participatory, with stakeholders taking part in the elaboration of the research instrument, field work, and discussion of results.

\section{Data collection}

Data were collected in late 1997 in all cities using the same self-administered, multiple-choice questionnaire. All students from grades 5 to 8 in classes indicated by the schools as having participated in the program in either Rio de Janeiro or Belo Horizonte were invited to complete the questionnaire. In the schools used for comparison (controls), all students from grades 5 to 8 were invited to respond to an identical 
General characteristics of three sex education programs in Brazil.

\begin{tabular}{|c|c|c|c|}
\hline Characteristics & Rio de Janeiro* & Belo Horizonte ${ }^{\star \star}$ & Salvador ${ }^{\star \star \star}$ \\
\hline Program duration (years)\# & 4 & 4 & 4 \\
\hline Duration of training (hours) & 80 & 80 & 80 \\
\hline Number of schools & 148 & 60 & 18 \\
\hline Number of teachers trained & 341 & 240 & 191 \\
\hline Number of health centers & 37 & 0 & 14 \\
\hline Number of health professionals trained & 84 & 0 & 32 \\
\hline Number of adolescent peer educators trained & 2,067 & 0 & 311 \\
\hline Number of adolescents directly involved & 14,520 & 18,494 & 11,948 \\
\hline
\end{tabular}

* Data obtained from http://members.tripod.com/CEDUS/educarte.html on 20/Mar/2003.

** Data obtained from http://www.educacao.mg.gov.br/see/cirino/paginas/historico.htm on 20/Mar/2003.

*** Data obtained from http://www.protagonismojuvenil.org.br/amigos/CRIA/\#5 on 20/Mar/2003.

\# In partnership with the Odebrecht Foundation.

questionnaire. Enrollment of schools to participate in the sex education programs was determined by local program managers, so it was not random. The program in Salvador had been developed in all the city schools, so there were no true comparison schools. Therefore, in Salvador the control schools were defined as those that begun implementing the program in 1997, while target schools were those that had initiated activities before 1997. Schools in each city were selected to participate in the study by simple random sampling (separately) from a list of program and comparison schools.

Only students ages 10 through 19 from target schools who declared having participated in sex education activities at school were considered participating adolescents. Adolescents in the same age bracket from control schools and who declared never having participated in any sex education activity comprised the control group.

The data collection instrument was developed by the research team from Cemicamp in collaboration with the local program managers in each city. The pre-tested, self-administered, multiple-choice KAP questionnaire contained 50 questions designed to provide answers to the program evaluation's specific objectives.

\section{Sample size}

Sample size was calculated from the estimated proportion (prevalence) of $50.4 \%$ of 15 to 19 years-old who declared having had sexual intercourse in a survey performed in the cities of Rio de Janeiro, Curitiba, and Recife ${ }^{4}$. Alpha was set at 0.05 and beta at 0.10 . The absolute difference between the programs' and the control groups' proportions was set at $8.0 \%$, resulting in 838 students per group in each municipality 5 .

The final sample size did not reach the desired number, although it was never less than 40 cases per group for questions regarding sexual practices. In this case, sample precision was estimated at $32.0 \%$ (alpha was set at 0.05 and beta at 0.20) based on data from the 1996 Brazilian Demographic and Health Survey 2, in which $20.0 \%$ of adolescents reported previous sexual intercourse.

\section{Study variables}

The main knowledge outcomes referred to sexuality, reproductive physiology, contraception, and sexually transmitted infections (STI), including HIV/AIDS. Attitudes referred to sexuality, citizenship, and gender, including whether the respondents felt at ease talking about sexuality. Finally, there were questions on current sexual activity, condom use, and modern contraceptive methods utilization.

For variables related to adolescents' knowledge, indicators were constructed from scores derived from the number of correct answers to a battery of questions for each specific variable. The indicator of gender attitudes was defined by a group of 16 activities related to the individual, domestic, and public dimensions of gender. Students were asked to state whether they considered each of them as being associated with males, females, or both genders. The expected attitude was that students would associate the highest possible number of activities with both genders. The indicator of attitudes toward sexuality involved agreement or disagreement with 13 statements concerning 
myths and taboos frequently associated with this topic. The indicator of attitudes toward citizenship was based on 18 daily situations involving personal interrelationships which students were asked to rank as never, sometimes, or always acceptable to them. The scores had different ranges and were dichotomized using median values of sample data.

The questionnaire also allowed the research team to collect demographic information on age, sex, skin color, grade in school, employment, and number of extra-curricular activities taken. These variables were included in the analysis as statistical controls.

\section{Data analysis}

Data analysis was performed separately for each city. Initially, bivariate statistical analyses investigated possible differences between groups in students' demographic characteristics and sexual practices. These analyses were performed separately for programs and controls, using Yates chi-square test 6 .

Multiple logistic regression analyses examined the relationship between groups (programs and controls) and each of the following dependent variables: knowledge about sexuality, reproductive physiology, contraception, STI/AIDS, and HIV transmission; attitudes on sexuality, gender, citizenship, whether the respondent felt at ease talking about sexuality, and current sexual activity, current condom use, and current use of a modern contraceptive method. Six other control variables: sex (male: 1 /female: 0 ); age (years); skin color (white: 1/non-white: 0 ); school grade (5th and $6^{\text {th: }} 0 / 7^{\text {th }}$ and $8^{\text {th: }} 1$ ); employment (yes: 1/no: 0); number of extra-curricular activities $(\leq 1: 0 />1: 1)$ were entered into the models. Stepwise selection was used to adjust the regression models for all variables except "group", which was entered into all models. Results of logistic regression analyses are presented only for "group" as adjusted odds ratio with the respective $95 \%$ confidence interval 7 .

All data entry and statistical analyses used SPSS 6.0.

\section{Ethical considerations}

Before participating in the study, students were asked to sign a free informed consent form ensuring adherence to the ethical principles of social science research, under the respective Resolution by the Brazilian Health Council, Ministry of Health ${ }^{8}$. Students 17 years or under were required to provide written consent from a parent or legal guardian. The research program and consent form were approved by the Institutional Review Board/Ethics Committee of the State University of Campinas.

\section{Results}

\section{Sample description}

More females than males were participating in the program in Belo Horizonte. In Salvador the program adolescents were significantly younger than the controls, while no age differences were found between the two groups in Rio de Janeiro or Belo Horizonte. In addition, more controls than program adolescents described themselves white-skinned in Belo Horizonte. Self-declared skin color distribution showed no statistical differences between participants and controls in Salvador and Rio de Janeiro (Table 2).

\section{Knowledge on sexuality}

Adolescents participating in the sex education program in Salvador had better knowledge on sexuality than controls. Participating adolescents from the three cities had significantly greater knowledge of reproductive physiology than controls, with the odds ratio varying from 1.60 to 1.79. In Belo Horizonte, participating adolescents also showed greater knowledge of STI/HIV/AIDS than controls (Table 3).

\section{Attitudes on sexuality, citizenship, and gender issues}

Adolescents participating in the programs in Rio de Janeiro and Salvador showed more positive attitudes toward sexuality-related issues than controls. Only participating adolescents from Salvador reported feeling more at ease talking about sexuality and showed the expected attitudes towards citizenship issues in greater proportion than controls. Participating adolescents from Belo Horizonte expressed the expected gender attitudes in a significantly lower proportion than controls (Table 4).

\section{Self-reported sexual behavior by participating adolescents and controls}

More participants than controls in Belo Horizonte reported sexual activity in the previous three months, both in the bivariate and multivariate analyses $(60.4 \%$ and $36.4 \%$, respectively) $(\mathrm{OR}=2.49)$. Reported use of modern contraceptive methods was almost twice as frequent among Salvador's participating adolescents as 
Proportion of participants in the programs and control students according to certain characteristics, in each of the three cities. Rio de Janeiro, Belo Horizonte, and Salvador, Brazil.

\begin{tabular}{|c|c|c|c|c|c|c|}
\hline \multirow[t]{2}{*}{ Characteristics } & \multicolumn{2}{|c|}{ Rio de Janeiro } & \multicolumn{2}{|c|}{ Belo Horizonte } & \multicolumn{2}{|c|}{ Salvador } \\
\hline & Program & Control & Program & Control & Program & Control \\
\hline Gender & \multicolumn{6}{|c|}{ * } \\
\hline Female & 67.6 & 68.7 & 68.1 & 56.3 & 69.3 & 62.4 \\
\hline Male & 32.4 & 31.3 & 31.9 & 43.7 & 30.7 & 37.6 \\
\hline $\mathrm{n}$ & 383 & 380 & 370 & 449 & 387 & 327 \\
\hline Age (years) & & & & & \multicolumn{2}{|c|}{$\star$} \\
\hline $10-14$ & 55.7 & 60.6 & 60.3 & 65.5 & 55.2 & 44.4 \\
\hline $15-19$ & 44.3 & 39.4 & 39.7 & 34.5 & 44.8 & 55.6 \\
\hline $\mathrm{n}$ & 384 & 383 & 370 & 449 & 388 & 331 \\
\hline Skin color & \multicolumn{6}{|c|}{ * } \\
\hline White & 31.0 & 34.7 & 27.1 & 37.4 & 13.1 & 11.7 \\
\hline Non-white & 69.0 & 65.3 & 72.9 & 62.6 & 86.9 & 88.3 \\
\hline $\mathrm{n}$ & 378 & 369 & 358 & 431 & 374 & 317 \\
\hline
\end{tabular}

${ }^{*} p<0.01$.

compared to controls in the multivariate analysis, while in the bivariate analysis this proportion was one third more frequent. Both results were statistically significant (Tables 5 and 6).

\section{Discussion}

All three models of sex education and citizenship programs proved capable of improving adolescent knowledge on some sexuality-related issues, especially reproductive physiology. Salvador's program also appeared to have improved participants' attitudes towards sexuality and citizenship issues, besides contributing to the adoption of modern contraceptives by the more sexually active adolescents. Belo Horizonte's program, on the other hand, appeared to be associated with less positive attitudes towards gender equity, and more of its participants reported having engaged in sexual activity. Rio de Janeiro's model had no impact on the adoption of safer sex practices, but did improve the adolescents' attitudes towards sexuality.

There are a number of possible explanations for the observed differences between sites, not all necessarily related to the programs themselves, including the selection of classes in each of the intervention schools where the program took place. Since the programs were not part of an operational research study but had purely educational goals, the schools, classes, and students were not randomly selected to
Table 3

Adjusted odds ratio of having better knowledge of sexually-related issues: adolescents participating in the sex education programs compared with controls* in the three cities. Rio de Janeiro, Belo Horizonte, and Salvador, Brazil.

\begin{tabular}{|c|c|c|c|}
\hline Knowledge & $\begin{array}{l}\text { Rio de Janeiro } \\
\qquad\left(n_{1}=685\right)\end{array}$ & $\begin{array}{l}\text { Belo Horizonte } \\
\qquad\left(n_{2}=757\right)\end{array}$ & $\begin{array}{l}\text { Salvador } \\
\left(n_{3}=630\right)\end{array}$ \\
\hline Sexuality (score $>1^{\star \star}$ ) & $\begin{array}{c}1.11 \\
{[0.81-1.52]}\end{array}$ & $\begin{array}{c}0.90 \\
{[0.66-1.21]}\end{array}$ & $\begin{array}{c}1.76 \\
{[1.24-2.50]}\end{array}$ \\
\hline $\begin{array}{l}\text { Reproductive physiology } \\
\left(\text { score }>3^{\star *}\right)\end{array}$ & $\begin{array}{c}1.79 \\
{[1.24-2.59]}\end{array}$ & $\begin{array}{c}1.60 \\
{[1.16-2.21]}\end{array}$ & $\begin{array}{c}1.67 \\
{[1.08-2.58]}\end{array}$ \\
\hline Contraception (score $>3^{\star \star}$ ) & $\begin{array}{c}1.17 \\
{[0.80-1.71]}\end{array}$ & $\begin{array}{c}1.03 \\
{[0.72-1.47]}\end{array}$ & $\begin{array}{c}1.09 \\
{[0.73-1.63]}\end{array}$ \\
\hline STI/AIDS (score $>4^{\star \star}$ ) & $\begin{array}{c}1.18 \\
{[0.86-1.62]}\end{array}$ & $\begin{array}{c}1.47 \\
{[1.08-1.99]}\end{array}$ & $\begin{array}{c}1.31 \\
{[0.95-1.79]}\end{array}$ \\
\hline $\begin{array}{l}\text { HIV transmission } \\
\left(\text { score }>8^{\star \star}\right)^{\star \star \star}\end{array}$ & $\begin{array}{c}1.24 \\
{[0.90-1.72]}\end{array}$ & $\begin{array}{c}1.05 \\
{[0.77-1.44]}\end{array}$ & $\begin{array}{c}1.05 \\
{[0.75-1.46]}\end{array}$ \\
\hline
\end{tabular}

* Exposure variable (yes: sex education group; no: control group). ** These variables were divided into categories according to the median. $\star \star \star$ Rio de Janeiro: $\mathrm{n}_{1}=701$; Belo Horizonte: $\mathrm{n}_{2}=770$; Salvador: 656 . Note: significant odds are highlighted in bold. 
participate. It is thus possible that the adolescents who were considered to be at higher risk were selected to participate in the programs. As there was no baseline information available for the three programs, it was not possible to assess differences between control and intervention schools prior to the initiation of the programs. If adolescents with less knowledge and

Table 4

Adjusted odds ratio of expressing an expected attitude toward sexuality, citizenship, and gender issues: adolescents participating in sex education programs compared with controls*, in three cities. Rio de Janeiro, Belo Horizonte, and Salvador, Brazil.

\begin{tabular}{|c|c|c|c|}
\hline Attitudes & Rio de Janeiro & Belo Horizonte & Salvador \\
\hline Sexuality (score $>6^{\star \star}$ ) & $\begin{array}{c}1.45 \\
{[1.06-1.99]} \\
(n=658)\end{array}$ & $\begin{array}{c}0.94 \\
{[0.69-1.27]} \\
(n=754)\end{array}$ & $\begin{array}{c}1.62 \\
{[1.12-2.33]} \\
(n=627)\end{array}$ \\
\hline $\begin{array}{l}\text { Respondent felt at ease } \\
\text { talking about sexuality }\end{array}$ & $\begin{array}{c}1.08 \\
{[0.80-1.46]} \\
(n=701)\end{array}$ & $\begin{array}{c}0.94 \\
{[0.70-1.25]} \\
(n=768)\end{array}$ & $\begin{array}{c}1.47 \\
{[1.05-2.07]} \\
(n=642)\end{array}$ \\
\hline $\begin{array}{l}\text { Citizenship issues } \\
\left(\text { score }>14^{\star \star}\right)\end{array}$ & $\begin{array}{c}1.27 \\
{[0.92-1.74]} \\
(n=655)\end{array}$ & $\begin{array}{c}0.92 \\
{[0.68-1.23]} \\
(n=749)\end{array}$ & $\begin{array}{c}1.51 \\
{[1.10-2.08]} \\
(n=619)\end{array}$ \\
\hline Gender issues (score $>10^{\star \star}$ ) & $\begin{array}{c}1.32 \\
{[0.97-1.80]} \\
(n=691)\end{array}$ & $\begin{array}{c}0.59 \\
{[0.45-0.78]} \\
(n=756)\end{array}$ & $\begin{array}{c}1.32 \\
{[0.95-1.84]} \\
(n=645)\end{array}$ \\
\hline
\end{tabular}

* Exposure variable (yes: sex education group; no: control group).

** These variables were divided into groups according to the median.

Note: significant odds are highlighted in bold. less positive attitudes or behaviors were included in the programs, any improvement resulting from the intervention may have placed them just at the level of control adolescents, who already had better knowledge, attitudes, or behavior beforehand. If so, any impact from the programs would be undetectable by the methodological design used in this evaluation. In addition, the evaluation focused on program results rather than processes. Due to these limitations, some questions remain unanswered.

Despite such limitations, there were strategic differences between the three models which could also explain greater changes in Salvador than in Rio de Janeiro or Belo Horizonte. For example, Belo Horizonte's program did not involve health professionals or health centers in its implementation strategy, while a partnership was established between health centers and schools in the other two cities. Another striking difference between Salvador's program and the other two was its strong emphasis on participants' involvement in creative activities such as theater skits and dramatization. It was not clear why Rio de Janeiro's program did not appear to have promoted the adoption of safe sex practices among its participants, since it implemented two important strategies for reaching this objective: a partnership with the health sector and training of over two thousand peer educators.

Other factors may also have influenced the different results in the three cities. Exposure to other sources of information and other factors that may have induced attitude and behavioral

Proportion of participants and control students who reported being sexually active, in each of the three cities. Rio de Janeiro, Belo Horizonte, and Salvador, Brazil.

\begin{tabular}{|c|c|c|c|c|c|c|}
\hline \multirow[t]{2}{*}{ Practices } & \multicolumn{2}{|c|}{ Rio de Janeiro } & \multicolumn{2}{|c|}{ Belo Horizonte } & \multicolumn{2}{|c|}{ Salvador } \\
\hline & Program & Control & Program & Control & Program & Control \\
\hline \multirow[t]{2}{*}{ Current sexual activity } & \multicolumn{6}{|c|}{$\star$} \\
\hline & 57.9 & 63.6 & 60.4 & 36.4 & 57.7 & 55.2 \\
\hline $\mathrm{n}$ & 114 & 121 & 111 & 118 & 123 & 116 \\
\hline Current use of condom & 53.0 & 44.2 & 45.5 & 57.1 & 45.7 & 40.6 \\
\hline $\mathrm{n}$ & 66 & 77 & 66 & 42 & 70 & 64 \\
\hline \multirow{2}{*}{$\begin{array}{l}\text { Current use of modern } \\
\text { contraceptive methods }\end{array}$} & & & & & \multicolumn{2}{|c|}{$\star \star$} \\
\hline & 72.7 & 75.3 & 67.2 & 80.0 & 82.6 & 61.3 \\
\hline $\mathrm{n}$ & 66 & 77 & 67 & 40 & 69 & 62 \\
\hline
\end{tabular}

$\star p<0.01$

$\star \star x<0.05$. 
changes may also have differed in each city. One indication of other such external factors is the lack of differences in knowledge on HIV transmission and contraception between participants and control adolescents in all three cities. Exposure to other sources of information on the two subjects has been almost universal in Brazil during the past decade. Indeed the 1996 Brazilian Demographic and Health Survey 2 showed that $87.6 \%$ of females and $86.3 \%$ of males ages 15 to 19 knew or had heard of HIV/ AIDS, and that television was their main source of information, mentioned twice as often as the second most frequent source. Thus, any increment in this area caused by the programs would be diluted and insufficient to show any significant differences between participating adolescents and controls.

In this study, 41.0 to $57.0 \%$ of sexually active participating adolescents reported condom use. Similar data were found in another more recent probabilistic national survey, where $44.4 \%$ of youth ages 16 to 25 reported having used condoms in the previous 12 months 1 . Even higher condom use was found among students in Salvador, where $72.0 \%$ of males and $51.0 \%$ of females reported condom use during their last intercourse 9. However, the Brazilian Demographic and Health Survey 2 found a much lower proportion of condom use: only $14.7 \%$ of sexually active youth ages 15 to 24 reported having used condoms as a contraceptive method in the four weeks prior to the interview. This difference could be explained by the type of question posed in the two surveys: while the Brazilian Demographic and Health Survey 2 asked about condoms as a contraceptive method, in the current study the question on condom use was related to STI/HIV/AIDS prevention. In addition, our study deals with young people who have attended school for at least 4 to 8 years, while the Brazilian Demographic and Health Survey 2 covers the overall population, and there is strong evidence from the Brazilian Demographic and Health Survey 2 data that condom use increases with years of education.

Both the Brazilian Demographic and Health Survey 2 and our own data showed a pattern of good knowledge of HIV prevention, but still limited adoption of safe sex practices. Although knowledge is an essential factor for behavioral change, it is certainly not sufficient $10,11,12$. The AIDS Risk Reduction Model adds skills to enact the desired behavior to the need for accurate information about risk behavior 13,14. Such skills could not be assessed from this KAP study. It is also important to highlight the limitations of this type of quantitative approach for
Table 6

\begin{tabular}{|c|c|c|c|}
\hline Practices & Rio de Janeiro & Belo Horizonte & Salvador \\
\hline Current sexual activity & $\begin{array}{c}0.71 \\
{[0.40-1.25]} \\
(n=217)\end{array}$ & $\begin{array}{c}2.49 \\
{[1.56-3.97]} \\
(n=217)\end{array}$ & $\begin{array}{c}0.98 \\
{[0.57-1.69]} \\
(n=220)\end{array}$ \\
\hline Current condom use & $\begin{array}{c}1.07 \\
{[0.64-1.77]} \\
(n=134)\end{array}$ & $\begin{array}{c}0.83 \\
{[0.51-1.36]} \\
(n=105)\end{array}$ & $\begin{array}{c}1.08 \\
{[0.51-2.28]} \\
(n=126)\end{array}$ \\
\hline $\begin{array}{l}\text { Current use of modern } \\
\text { contraceptive methods }\end{array}$ & $\begin{array}{c}0.75 \\
{[0.35-1.65]} \\
(n=134)\end{array}$ & $\begin{array}{c}0.50 \\
{[0.20-1.28]} \\
(n=104)\end{array}$ & $\begin{array}{c}2.82 \\
{[1.45-5.49]} \\
(n=124)\end{array}$ \\
\hline
\end{tabular}

* Exposure variable (yes: sex education group; no: control group).

capturing the context and complexity of decisions involving sexual behavior 15 .

However, as Kirby 16 (p. 177) points out, "no known programs currently exist that dramatically reduce sexual risk-taking behavior". In an extensive literature review published by the Joint United Nations Program on HIV/AIDS (UNAIDS) 17 on the impact of HIV and sexual health education on the behavior of young people, six out of 15 controlled intervention studies failed to show a relationship between sexual health education and sexual activity. Although it is widely known that sex education does not generally lead to earlier engagement in sexual activity, it is essential for educators and program managers to have realistic expectations about the impact that such programs are capable of creating 15,17.

Minas Gerais' Education and Health Secretariats are working together to apply the lessons learned from this evaluation to the implementation of a new school-based sex education program, called the Program of Sexuality and Affectivity Education: A New View. Changes adopted by this new program include a new training curriculum for trainers, collaboration between the Education and Health Secretariats, and a monitoring and evaluation system, which started with a baseline survey prior to program implementation. The latter is part of a quasi-experimental evaluation design involving pre and post-tests and non-equivalent control groups. This experience, which combines the public sector with local private donors in the evaluation of an entire State health and educational system, is unique to Brazil and should 
provide valuable information for the continued improvement of educational programs aimed at reducing the risk of unwanted pregnancy and disease among adolescents.

\section{Resumo}

Três programas de educação sexual e cidadania, em escolas públicas do Rio de Janeiro, Belo Horizonte e Salvador, Brasil, foram avaliados por meio de um estudo de corte transversal, comparando-se adolescentes da $5 \underline{a}$ a $8 \underline{a}$ série que participaram dos projetos, com adolescentes de escolas não-participantes. Os resultados mostraram que em Salvador houve mudanças significativas no conhecimento sobre sexualidade e fisiologia da reprodução, atitudes em cidadania e no uso atual de anticoncepcionais modernos. No Rio de Janeiro houve mudanças positivas no conhecimento sobre fisiologia da reprodução e melhoria das atitudes em sexualidade; o projeto de Belo Horizonte mostrou um maior conhecimento sobre fisiologia reprodutiva e prevenção das DST/AIDS, atitudes em gênero menos favoráveis e uma maior atividade sexual. A principal característica do projeto de Salvador foi, a centralização das ações em atividades culturais. O projeto de Belo Horizonte era o único que não havia estabelecido parceria com o setor da saúde, mas, após a avaliação, redefiniu sua estratégia de capacitação e iniciou uma expansão para todo o estado, em uma ação conjunta das Secretarias Estaduais de Saúde e de Educação.

Educação Sexual; Adolescente; Avaliação

\section{Contributors}

All the authors participated in drafting the article and in all stages of the research.

\section{Acknowledgments}

We are extremely grateful to the local NGOs (Cedus, Cria, Humbi-Humbi, and Prossex) and to the Education and Health Secretariats of the cities of Rio de Janeiro, Salvador, and Belo Horizonte, who implemented the programs and collaborated with this evaluation. We also wish to thank Maria Silvia Bruni Fruet, María Yolanda Makuch, Eliana Hebling, Juan Díaz, and all those who collaborated directly or indirectly with this study. We are indebted to Ruth Simmons and Laura Ghiron for their helpful comments on previous drafts of the manuscript. The study was funded by the Odebrecht Foundation. 


\section{References}

1. Centro Brasileiro de Análise e Planejamento/Ministério da Saúde. Comportamento sexual da população brasileira e percepções sobre o HIV/AIDS. Brasília: Ministério da Saúde; 2000.

2. Sociedade Civil Bem-estar Familiar no Brasil. Adolescentes, jovens e a Pesquisa Nacional sobre Demografia e Saúde: um estudo sobre fecundidade, comportamento sexual e saúde reprodutiva. Rio de Janeiro: Sociedade Civil Bem-estar Familiar no Brasil; 1999.

3. Ministério da Saúde. Boletim Epidemiológico AIDS 2000; Ano XIII, n. 1.

4. Sociedade Civil Bem-estar Familiar no Brasil. Pesquisa sobre saúde reprodutiva e sexualidade do jovem - Rio de Janeiro, Curitiba e Recife. Rio de Janeiro: Sociedade Civil Bem-estar Familiar no Brasil; 1992.

5. Fleiss JL. Statistical methods for rates and proportions. 2nd Ed. New York: John Wiley \& Sons; 1981.

6. Altman DG. Practical statistics for medical research. London: Chapman and Hall; 1991.

7. Hosmer DW, Lemeshow S. Applied logistic regression. New York: John Wiley \& Sons; 1989.

8. Conselho Nacional de Saúde. Resolução 196/96 sobre pesquisa envolvendo seres humanos. Bioética 1996; 4:15-25.

9. Magnani RJ, Gaffikin L, Aquino EML, Seiber EE, Almeida MCC, Lipovsek V. Impact of an integrated adolescent reproductive health program in Brazil. Stud Fam Plann 2001; 32:230-43.

10. Díaz MM. Condutas sexuais e atitudes que constituem fatores de risco para gravidez não desejada e AIDS em estudantes universitários: um desafio para a educação sexual [Dissertação de Mestrado]. Campinas: Faculdade de Educação, Universidade Estadual de Campinas; 1994.
11. Dockrell J, Dockrell WB. An evaluation of teaching fifteen year olds about HIV/AIDS. Studies in Educational Evaluation 1995; 21:43-56.

12. Chirinos JL, Salazar VC, Brindis CD. A profile of sexually active male adolescent high school students in Lima, Peru. Cad Saúde Pública 2000; 16:733-46.

13. Boyer CB, Shafer M-A, Tschann JM. Evaluation of a knowledge and cognitive-behavioral skillsbuilding intervention to prevent STDs and HIV infection in high school students. Adolescence 1997; 32:25-42.

14. Paiva V. Fazendo arte com camisinha: sexualidades jovens em tempos de AIDS. São Paulo: Summus; 2000.

15. Kassirer A, Griffiths J. The effectiveness of "The Responsible Sexuality Program": a brief high school sexual education intervention. J Sex Educ Ther 1997; 22:5-11.

16. Kirby D. School-based prevention programs: design, evaluation, and effectiveness. In: DiClemente RJ, editor. Adolescents and AIDS: a generation in jeopardy. Newbury Park: Sage Publications; 1992. p. 159-80.

17. Joint United Nations Program on HIV/AIDS. Impact of HIV and sexual health education on the sexual behavior of young people: a review update. Geneva: Joint United Nations Program on HIV/AIDS; 1997.

Submitted on 12/Feb/2004

Final version resubmitted on 19/Aug/2004

Approved on 03/Sep/2004 